\title{
WORKING MOTHER'S KNOWLEDGE ON HOW TO STORAGE ASI IN POSYANDU MATAHARI ,THE WORKING AREA OF THE PUSKESMAS BOTANIA
}

\author{
Wenas $^{1}$, Muhammad Dezarino ${ }^{2}$ \\ wennas@univbatam.ac.id ${ }^{\mathbf{1}}$, muhammaddezarino@univbatam.ac.id ${ }^{\mathbf{2}}$ \\ Professional Doctor Study Program, Faculty of Medicine, Batam University ${ }^{1}$ \\ Medical Education Study Program, Faculty of Medicine, Batam University ${ }^{2}$ \\ Jl. Abulyatama No 5 - Kota Batam
}

\begin{abstract}
Background : Exclusive breastfeeding is the best food for babies, but in its implementation there are many obstacles, one of which is the mother working so that she has to leave the baby at home. Working mothers can still do exclusive breastfeeding by expressing milk in the workplace, and providing four clean and closed ones for expressing. The target for achieving exclusive breastfeeding set by the Ministry of Health is $80 \%$, while in Indonesia in 2015 the target was $71.62 \%$. The purpose of this study was to determine the knowledge of working mothers on how to store breast milk.
\end{abstract}

Method: The research method used was descriptive, carried out at the Matahari Posyandu, the working area of the Botania Community Health Center, the study was conducted for 6 months, the population in this study were all working mothers who had babies $0-12$, the sample was 43 people with the sampling technique using total sampling, instrument. research using a questionnaire.

Result : The results showed that most of the respondents had good knowledge, namely 35 people (81.4\%), while 8 people (18.6\%) had poor knowledge.

Conclusion : The conclusion that can be taken is that most working mothers who have babies have knowledge. good about how to store breast milk. It is recommended that the mother of the baby is always looking for information about breast milk so that she can continue to give her breast milk

Keywords: Knowledge, Working Mother, Breastfeeding Storage

\section{INTRODUCTION}

Breastmilk (ASI) is the best natural nutrition for babies because it contains the energy and substance needs needed for the first six months of a baby's life (Rosita, 2008)

Exclusive breastfeeding is also very helpful in reducing the high infant mortality rate in Indonesia, which has now reached 30,000 infant deaths each year. Press releases sent by UNICEF, the number of babies in Indonesia who receive exclusive breastfeeding continues to decline. If the baby is not exclusively breastfed, it is possible that the child will experience malnutrition and about $15-20 \%$ of brain cells do not develop normally. Babies who are not exclusively breastfed are more prone to diarrhea, respiratory problems and others. More than $40 \%$ of deaths are caused by diarrhea and acute respiratory infections (ISPA), diseases that can be prevented by exclusive breastfeeding (Roesli, 2008).

Exclusive breastfeeding is the best food for babies, but in its implementation there are many obstacles, including the mother's lack of understanding of correct lactation management, the baby is already getting prelacteal feeding (sugar water or formula) on the first day of birth, mother's nipple disorders, baby difficulties in sucking, pregnant women again while still breastfeeding, mothers working so they have to leave their babies at home, the desire to be called modern, and the influence of formula milk advertising is increasingly intense1). Mothers who work outside the home must leave their babies for a certain period of 
time, which is one of the limitations of being able to directly breastfeed the babies while working. The 2012 Indonesian Health Demographic Survey (IDHS) shows that the coverage of exclusive breastfeeding in Indonesia is $42 \%$. Data from the Deputy Minister for National Development Planning / Head of the National Development Planning Agency (BAPPENAS), the achievement of the target for exclusive breastfeeding in 2013 was only $54.3 \%$ of the total population of $2,483,485$ babies and the target to be achieved is based on the National Medium-Term Development Plan (RPJMN) year Upcoming 2019 is $80 \%$

Breastfeeding activities often encounter various obstacles. One of the factors that influence exclusive breastfeeding is mothers who work outside the home, so they cannot provide exclusive breastfeeding for 6 months to their babies. In Indonesia, leave for pregnant and breastfeeding mothers ranges from 1-3 months. . A mother who has finished her leave period must return to work, even though she is still breastfeeding. This is one of the obstacles in exclusive breastfeeding. Based on the Republic of Indonesia Government Regulation Number 33 of 2012 article 6, that every mother who gives birth must provide exclusive breastfeeding to the baby who is born. Exclusive breastfeeding can actually be done, even though there is no direct contact with the baby when he is left at work An alternative way that can be taken is by giving breast milk. Strong motivation and extra patience are needed to be able to provide breast milk. Mothers should start saving breast milk 1 month before returning to work. Expressed breast milk can be stored and can then be prepared for feeding to a baby without having to think about modifying it with formula

Breastfeeding for mothers who work in offices is a challenge in itself. If the office environment is accustomed to this situation, surely the problem will be reduced a little. At least mothers can express breastmilk in a special room, and can also store their milk without hiding in the office refrigerator. Problems arise when the office environment is not supportive, either because they do not know the importance of exclusive breastfeeding, or because they do not want to know because they think that giving special dispensations to mothers to express breastmilk can be obtained. consider favoritism Exclusive breastfeeding can still be done by working mothers by expressing milk at the workplace, and providing a clean and closed place for expressing14). Between working hours, mothers can express breastmilk every 23 hours. Expressing breast milk can be done by hand and pump 8). But there are also many mothers who stop breastfeeding and do not express their milk at work because they do not know other ways if they are not fed on their babies, even some mothers just throw their milk away15). Not breastfeeding the child can have an impact on the health of the mother because if the mother does not breastfeed, it will affect milk production, hormones, and the health of the mother's breast.

The lack of knowledge of working mothers about how to store breast milk is a factor that affects the failure of exclusive breastfeeding. The correct storage of breast milk is breast milk is stored using glass bottles, breast milk storage at room temperature $16-29^{\circ} \mathrm{C}$ can last in 3-6 hours, if stored in a refrigerator with a temperature of $0-4{ }^{\circ} \mathrm{C}$ breast milk can last up to 3-8 months, storage in the freezer one door refrigerator, breast milk is safe for consumption for up to 2 weeks, and if breast milk is stored in a special freezer with a very cold temperature of $-18^{\circ} \mathrm{C}$, breast milk is safe for storage for up to 6-12 months (Riksani, 2012). Although expressed breast milk cannot replace direct breastfeeding, it creates a problem for working mothers. Many mothers worry and think that their breast milk cannot meet the needs of their babies while the mother is working. This causes mothers to switch and give formula milk to their babies, even though working mothers can still exclusively breastfeed their babies by expressing and storing them.

Based on Article 128 paragraphs 2 and 3, Law Number 36 of 2009 concerning Health states that during breastfeeding, the family, local government and the community must fully support the mother by providing special time and facilities at workplaces and public 
facilities2). Article 200, the criminal sanction imposed for every person who deliberately obstructs the exclusive breastfeeding program is a maximum of 1 (one) year in prison and a maximum fine of Rp. 100,000,000.00 (one hundred million rupiah)

Based on data obtained from the Batam City Health Office. The highest number of mothers who have babies is in the Botania Community Health Center (Puskesmas) working area as many as 4093 people and the coverage of exclusive breastfeeding is still far below the national target of $80 \%$.

Data from the pre-survey that was conducted on 10 mothers working at the Matahari Posyandu, only 2 mothers applied breastfeeding storage, while 8 people gave formula milk.

Based on the data obtained above, the lack of knowledge of mothers working by storing breastmilk is why the authors are interested in raising this issue into a study entitled "Knowledge of Working Mothers on How to Store Breast Milk in the Posyandu Matahari, the working area of the Botania Community Health Center"

\section{RESEARCH PURPOSES}

This study aims to determine the knowledge of mothers about how to store breast milk in the Matahari Posyandu, the working area of the Botania Community Health Center

\section{RESEARCH METHODOLOGY}

The research method used was descriptive, carried out at the Matahari Posyandu, the working area of the Botania Community Health Center, the study was conducted for 6 months, the population in this study were all working mothers who had babies $0-12$, the sample was 43 people with the sampling technique using total sampling, instrument. research using a questionnaire

\section{RESEARCH RESULT}

Table 1

The frequency distribution of respondents is based on the knowledge of working mothers about how to store breast milk

\begin{tabular}{ccc}
\hline Knowladge & Frekuensi (f) & Presentase (\%) \\
\hline Good & 35 & 81,4 \\
\hline Less & 8 & 18,6 \\
\hline Total & $\mathbf{1 0 0}$ & $\mathbf{1 0 0}$ \\
\hline
\end{tabular}

Based on table 1, it is found that most of the respondents have good knowledge, namely as many as 35 people $(81.4 \%)$, while the poor knowledge is as many as 8 people $(18.6 \%)$.

\section{DISCUSSION}

From the results of the study that measured the knowledge of working mothers on how to store breast milk, it was found that the majority of respondents had good knowledge, namely 35 people (81.4\%).

Almost all respondents have good knowledge, this is possible because mothers get information through magazines, newspapers, internet, television, as well as from colleagues.

Knowledge is a very important domain for the formation of one's behavior (Notoadmodjo
2015). Knowledge is human sensing, or the result of someone knowing an object through the senses they have. According to Notoatmodjo (2016), the measurement of knowledge can be carried out by means of interviews or questionnaires that ask about the content of the material to be measured from the research subject or respondent. A person's knowledge can be influenced by factors that a person has, namely age, education and work

According to research conducted by Susanti (2012), it shows that there is a relationship between the level of knowledge of working 
mothers on how to store breast milk and exclusive breastfeeding for babies 6-12 months ( $\mathrm{p}$ value $=0.002)$. According to him, the knowledge of working mothers about how to store breast milk is an important factor in exclusive breastfeeding, because with good knowledge, someone will find it easier to understand information about the importance of exclusive breastfeeding so that it can be applied in everyday life.

Storage of breast milk or storing breastmilk is an effort or solution that can be used for mothers who work or are not always at home and not always with their babies. Breast milk storage can be done by: storing breast milk in bottles that have a tight lid, breast milk can be stored with bottles or plastic clips $\pm 80-100 \mathrm{ml}$, store breast milk in the freezer, and if breast milk is stored at room temperature it can only last up to 2 hours. The results showed that both categories were influenced by age characteristics. Most of the respondents were $20-35$ years old $(77.8 \%)$ where the respondents had experience and maturity in thinking and doing activities, this age helped the respondents to receive a fairly good knowledge about breastfeeding storage. Mothers who have sufficient comprehension in receiving information about breastfeeding storage will certainly have quite good knowledge as well. If someone has a mature mindset and experience too. Age will greatly affect the catching power so that the knowledge it gets will be better (Ariani, 2014).

Knowledge is closely related to education, it is hoped that higher education will expand knowledge and make it easier to receive information so that it will affect behavior. In this case, especially the behavior of mothers in breastfeeding their babies and knowing how to give breastmilk when the mother is working

Most of the respondents have the last high school education level, as many as 33 respondents. The education that respondents receive is a form of obtaining knowledge that is useful for good attitudes in taking an action. Knowledge is closely related to education, where it is expected that with a high education, the person will have broader knowledge. However, it needs to be emphasized, it does not mean that someone with low education is absolutely low-knowledgeable (Wawandan Dewi, 2010).

How to express breastmilk using a hand pump includes pressing a rubber ball to release air, placing the wide end of the tube on the breast with the nipple right in the middle, and the tube is firmly attached to the skin of the breast, remove the rubber ball, so that the nipple and areola are pulled in, press and release several times so that the milk comes out and collects in the collection tube, and wash the appliance thoroughly using boiling water, after use or when it will be used

Dewi (2011) states that things that must be considered when storing breast milk are if the breastmilk is not in an air-conditioned room for no more than 4 hours, if it is in an airconditioned room the temperature of the room must remain stable if the breast milk bottle is in that room., immediately store breast milk in the refrigerator. Breast milk can last 8 days provided that breast milk is separated from food or vegetables while in the refrigerator, if there is no separate room for the refrigerator, then do not leave the bottle of breast milk in the refrigerator for $3 \times 24$ hours and can also separate breastmilk from plastic which is well cleaned.

Breastmilk that has been expressed and is not directly breastfed for babies should be stored directly in the refrigerator or ice thermos. But storage in an ice flask cannot be used for days. Storage of a refrigerator with two doors will be more durable in the freeze than a refrigerator with one door (Widuri, 2013).

How to give frozen breast milk to baby, namely: soaking a bottle of milk by soaking it in hot water, do not heat milk by boiling it in a pot or microwave unless the microwave has a special design for heating milk, estimate how much the baby is breastfeeding, so that not all 
of the water milk is heated, because milk that has been heated can no longer be stored (Dewi, 2011)

\section{CONCLUSION}

From the research conducted, it can be concluded that most of the respondents have good knowledge about how to store breast milk, namely as many as 35 people (81.4\%), while the lack of knowledge about how to store breast milk is as many as 8 people (18.6\%).

\section{SUGGESTION}

a. Share the research place

This research can be used as reference materials and as input for educational parties or institutions in order to increase the knowledge of working mothers about how to store breast milk with its application and it is hoped that the midwife will provide more counseling or counseling about how to provide breast milk with its application.

\section{b. For Educational Institutions}

It is hoped that the institution (institution) can socialize the importance of knowledge about how to store breast milk by its application to working mothers. This information can be notified by midwifery D-III educational institutions.

c. For mother

It is recommended that working mothers who store breastmilk be able to attach the time and date labels after expressing the milk, so that when working mothers do not forget the time the breast milk is stored in the refrigerator

\section{d. For further researchers}

can be an additional reference for further research and it is suggested further to add the number of attitude variables, behavior variables and to take the place of new and better research as a comparison of the results.

\section{DAFTAR PUSTAKA}

Khamzah N, Siti. Segudang Keajaiban ASI Yang Harus Anda Ketahui. Jogjakarta:

FlashBooks. 2012.

Soetjiningsih, Dr. ASI: Petunjuk Untuk Tenaga

Kesehatan. Jakarta: EGC. 1997.

Arief Nurhaeni. Panduan Ibu Cerdas (ASI dan

Tumbuh Kembang Bayi). Jogjakarta:

Media Pressindo. 2009.

Riksani Ria. Keajaiban ASI. Jakarta: Dunia Sehat. 2012.

Purwanti Sri Hubertin. Konsep Penerapan ASI

Eksklusif: Buku Saku Untuk Bidan. Jakarta: EGC. 2004.

Fiva Rosalana. Keajaiban ASI-Makanan Terbaik untuk Kesehatan, Kecerdasan, dan Kelincahan Si Kecil. Jogjakarta: Hak Cipta. 2010.

Fajar, Ibnu, dkk. Statistika Untuk Praktisi Kesehatan. Jogjakarta: Graha Ilmu, 2009. Jan Riordan. Buku saku menyusui dan laktasi. Jakarta: Buku Kedokteran EGC, 2000. Nina Siti. Asi dan Pedoman Ibu Menyusui. Yogyakarta: Nuha Medika, 2013.

Soetjiningsih. ASI: Petunjuk Untuk Tenaga Kesehatan. Jakarta, EGC, 1997.

Nawang Sawitri. ASI atau Susu Formula ya?. Jogjakarta, FlashBooks, 2011.

Muammar Kahddafi. Metodologi Penelitian SPSS. UNIBA PRESS Batam, 2010.

Manuaba. Ibu Bekerja Dengan Cara Penyimpanan ASI. Jakarta: Keyward. 2017

Ekowati. Pengertian Ibu Bekerja. Yogyakarta: Keyward. 2011

Baskoro, Anton. ASI Panduan Praktis ibu Menyusui, Jakarta: Banyu Media,2008.

Dinas Kesehatan Kota Batam. Profil Kesehatan Kota Batam tahun 2017. Batam Hartono dkk (ed 21). Jakarta: EGC, 2004.

Notoatmodjo, soekidjo. Metodologi Penelitian

Kesehatan. Jakarta: Rineka Cipta. 2010.

Suryaprojogo, Nadine. Keajaiban menyusui. Jogjakarta: Keyword. 2009.

Simki et al. Panduan Lengkap Kehamilan,Melahirkan ,dan Bayi (edisi Revisi). Jakarta:Arkan. 2008.

Notoatmodjo, soekidjo. Metodologi Penelitian Kesehatan. Jakarta: Rineka Cipta. 2005. Apri, susanti. Hubungan Tingkat Pengetahuan Ibu Bekerja Tentang Cara Penyimpanan ASI Dengan Pemberian ASI Eksklusif Pada Ibu 
ZONA KEDOKTERAN - Vol. 10 No. 3 September 2020

Yang Berkunjung Di Poli Anak. Yogyakarta.

2012

Khilmiana. Tingkat Hubungan Ibu Bekerja

Dengan Penyimpanan ASI. Jakarta: CGV.

2014

Setyowati. Cara Penyimpanan ASI.

Yogyakarta: Keyword. 2015 